\title{
TAX POLICY AND FISCAL COMPETITION IN THE EUROPEAN UNION
}

\author{
Associate Professor PhD Marilen Pirtea, E-mail: marilen.pirtea@fse.uvt.ro \\ Phd student Marius Miloş, \\ PhD student Laura Raisa Iovu \\ West University Of Timisoara, Romania
}

\begin{abstract}
Thus tax competition and harmonization efforts should set up a common and necessarily harmonized framework of a European tax system, there are pressing needs to promote the economic growth and welfare by increasing fiscal fairness.

Considering all this aspects, it is necessarily to analyze the tax policy in the European Union's countries, to see differences, evolutions and competition problems that may hinder economic integration. However the analyze focuses on the old countries of the European Union and also on the group of countries which entered European Union in may 2004. The conclusions and further analyses could also involve Romania and Bulgaria which have recently joined the Union and which have to harmonize taxes according to the European practices.
\end{abstract}

\section{INTRODUCTION}

During the '90s, ${ }^{1}$ almost all European countries introduced important changes in their tax systems, and they have planned many others. This fiscal revolution, which, so far, has not been deeply evaluated across European Union (EU), has been driven by many easily identifiable forces, which, interestingly, often conflict with each other. Usually fiscal reforms do not occur without being promoted by the interests and particular needs of a certain country or being determined by internal or external pressures.

\section{FINANCIAL RESOURCES IN THE EUROPEAN UNION}

\section{Trends in financial resources of the $\mathrm{EU}$}

Tax revenue ${ }^{2}$ paid to general government fell slightly in 2004 to $40.7 \%$ of GDP, from $40.9 \%$ in 2003. The decline was more marked in the euro-zone where the ratio fell from $41.5 \%$ in 2003 to $41.1 \%$ in 2004. Looking at the trend over the years 1995-2004, tax revenue in the EU-25 fell to its lowest level in terms of GDP in 2004. However, the most significant decrease was during the period 2000-2002, following the peak year of 1999 when the ratio of tax revenue to GDP had reached $42.4 \%$. The trend for the euro-zone over the same period follows closely that of the EU-25, but quite a different pattern emerges from the data for the new Member States (NMS-10). In these countries taxes are generally lower than in the EU-15, and during 1995-2000 there was a distinct fall in government tax revenue as a percentage of GDP in the NMS-10.

There are many reasons why government revenue from taxes and social contributions varies from year to year as a percentage of GDP. A much more in-depth analysis than the one presented here would be necessary to explain the causes of such variations in particular countries. Changes in

\footnotetext{
${ }^{1}$ Bernardi L., Profeta P., Tax Systems and Tax Reforms in Europe, Routledge, London 2004, p.1

2 Ohlsson L., Tax revenue in The E.U., Statistics in focus, Economy and Finance, Eurostat, 2/2006
} 
economic activity (affecting levels of employment, sales of goods and services, etc.) and in tax legislation (affecting tax rates, thresholds, exemptions, etc.) are the main reasons for differences in the amount of tax revenue recorded each year. It should be noted that, even using accrual methods of recording, the effects of changes in legislation or economic activity tend to have a delayed impact on tax revenue. Since 2000 significant declines in tax revenue as a percentage of GDP have occurred in Germany, Greece, the Netherlands, Slovakia, Finland, and Sweden. $\mathrm{In}^{3}$ Germany the ratio fell from a peak of $43.3 \%$ in 2000 to $40.0 \%$ in 2004. In the case of Greece and Finland the peak year was also 2000, the ratio falling from $40.9 \%$ to $37.7 \%$ for Greece and from $47.9 \%$ to $44.5 \%$ for Finland. Nevertheless, in Greece revenue as a percentage of GDP was higher in 2004 than in the years 1995-1997. In Slovakia tax revenue declined from 33.2\% to 30.6\% of GDP between 2000 and 2004, but the trend had in fact been clearly downward since 1995 when the ratio was $40.6 \%$. In the Czech Republic a different strategy has been adopted, keeping the ratio more or less stable since 1995.Between 2000 and 2004 significant increases in tax revenue as a percentage of GDP were recorded in Cyprus and especially Malta. In the case of Malta the ratio was $36.7 \%$ in 2004 compared with $30.1 \%$ in 2000. In Cyprus the ratio moved up from $30.0 \%$ in 2000 to $33.7 \%$ in 2004, but the upward trend had already begun in 1997 when the ratio was $25.8 \%$. The data for Estonia show little change between 2000 and 2004, but this follows a sharp downward trend between 1995 and 1999, so that tax revenue in 2004 (32.7\% of GDP) is much lower than in 1995 (37.9\%). Similarly, taking a longer view of the Polish data, the ratio has fallen considerably from $39.4 \%$ in 1995 to $34.3 \%$ in 2004.

As the figures show, the amount of tax revenue as a percentage of GDP is much lower generally in the new member states (NMS) than for the EU-15 countries. The most notable exception concerns Ireland, with a ratio of $31.7 \%$ in 2004 , below the NMS-10 average of $35.2 \%$. Nevertheless, beneath the Irish level are Lithuania (28.7\%), Latvia (29.1\%), and Slovakia (30.6\%). The new Member State with the highest level of tax revenue in terms of GDP is Slovenia, with 39.9\%. At the other end of the range are Sweden, with a ratio of tax revenue to GDP of $51.2 \%$ in 2004, followed by Denmark (49.9\%), Belgium (47.4\%), and France $(45.3 \%)$. For the majority of the 25 countries the ratio comes within a range of $35-45 \%$ of GDP. Weighted by countries' GDP, the average level in the EU-25 is $37.7 \%$ in 2004.

\section{Taxes levied at different levels of government}

Taxes are usually classified according to four different units of government that may operate within a country and to the Institutions of the E.U. The combination of the different government levels operating within a member state is called the general government, and may include depending on the fiscal authority: ${ }^{4}$ central (or federal or national) government, including all administrative departments and central, agencies of the state whose competence extends normally over the whole economic territory, except for the administration of the social security funds; state (or regional) governments which are separate institutional units exercising some of the functions of government at a level below that of central government and above that at local level, except for the administration of social security funds; local (or municipal) government, whose competence extends to only a local part of the economic territory, apart from local agencies or social security funds; social security funds, including all central, state and local institutional units whose principal activity is to provide social benefits.

\footnotetext{
${ }^{3}$ Markiewicz M., Corporate Income Taxation and FDI in the EU-10, 2004

${ }^{4}$ European Commission Directorate General- Taxation and Customs Union, Eurostat, Structures of the taxation systems in The European Union, 2004

${ }^{5}$ European Commission Directorate General- Taxation and Customs Union, Eurostat, Structures of the taxation systems in The European Union, 2004
} 
In $2002,{ }^{5}$ in the EU-15 on average $52 \%$ of the 'ultimately received' aggregate tax revenue (including social contributions) is claimed by the central or federal government, roughly $30 \%$ accrues to the social security funds, $7 \%$ to the state government and almost $10 \%$ to local government sub-sectors. Around $1.1 \%$ of this tax revenue is paid to the Institutions of the European Union. There are however considerable differences from one member state to another. For example, the share of the total tax revenues received by the government sub-sectors (regions and municipalities) varies from less than $1 \%$ in Greece to $34.5 \%$ in Denmark. Not only Denmark, but also Sweden (32\%), Germany (28.3\%), Belgium (27.7\%), and Spain (26.7\%) show relatively high shares of total taxes received by government sub-sectors. The share is around the EU average in Austria (18.2\%) and Italy (15.2\%). The share is noticeably small in Greece (0.9\%), Ireland (2.3\%), the Netherlands (3.7\%) and the United Kingdom (4.4\%). What also stands out, furthermore, is that the figures for France and Germany show a relatively high share of tax receipts from social security funds.

It is interesting to follow the shares of direct and indirect revenues of the general government that is apportioned to local (municipalities), state (regions) governments (social security funds are not included). The greatest shares of tax revenues from local governments in EU-15 are found in the Scandinavian countries like Denmark (34.5\%), Sweden (32\%) and Finland (21.4\%). These shares are noticeably small in Greece $(0.9 \%)$, Ireland $(2.3 \%)$ and the United Kingdom $(4.4 \%)$. Only four countries within the EU-15 have tax revenues that are apportioned to the state governments (regions): Germany (21.6\%), Belgium (23\%), Spain (18.3\%) and Austria (7.2\%). Significant changes in the shares of tax revenues of state and local governments between 1995 and 2002 occurred in Spain and Italy. In Spain, an increase in the share of state tax revenue is firstly visible from 1997 onwards. This mainly reflects the introduction of the new five-year (1997-2001) arrangement for sharing tax revenues between the autonomous regions. In 2002 Spain witnessed a substantial increase of the share collected by state governments of more than 10 percent of total taxes, due to the new financing agreement between the central government and the autonomous regions. In Italy, an increase in the share of local tax revenues is visible from 1998 onwards. This can be attributed to the Italian reform that, among other important changes, introduced a new Regional Tax on Productive Activities ('IRAP'), and decreased the dependence of the local governments on grants from the central government.

In the new member states, the state government level does not exist. Concerning local government taxation the figures vary between Malta, which does not apply local taxation, to Latvia with a share of $16.8 \%$. Relatively high shares of local taxes can be seen also in Estonia (12.9\%), Hungary (10.6\%), Poland (10.2\%) and Lithuania (9.8\%). Concerning social security funds, high shares appear in Poland (40.9\%), Slovenia (38\%) and Lithuania (37.1\%).

\section{Trends in corporate taxation and tax burden}

The corporate taxation is one of the main sources of public funds, its level giving an insight on the trend of economic developments. The share of corporate taxation in total tax revenues varies among the EU countries, but on average it is smaller in the EU-10 than in the EU-15. The two groups are clearly not homogenous: among the new member states, the Czech Republic collects the most corporate taxes (as much as Finland in terms of GDP) and Lithuania the least, while in the old member states Luxemburg generates the highest corporate income tax (CIT) revenues and Germany the least. During 1995-2002 both old and new member states decreased statutory CIT rates, but while this was associated with declining tax revenues in the EU-10, they were rising in EU-15 suggesting also rising effective tax rates. 
In 2004, average nominal corporate tax rates in the new member countries is about ten percentage points less than in the old member states, with the difference growing over the last decade. The trend to decrease statutory rates is continuing: the Czech Republic will reduce the rate by 2 percentage points annually over the next two years to $24 \%$ in 2006; Estonia will reduce its rate at a similar pace over the next three years to $20 \%$ in 2007; Latvia plans to cut its rate to $12.5 \%$ in 2005; and among the old EU members further cuts are planned in Austria, Finland, Netherlands, and Greece.

Beside the legal rates, there seems extremely important to determine the real rates collected from companies.

So among the old member states, Belgium, Germany, France and Italy had the highest CIT rates but relatively low revenues from corporate taxes, again suggesting that focus should be on effective taxation. In tandem with reducing CIT rates, many countries moved to broaden the tax base. Among the old member states, the tendency was to lower special incentive schemes or tax allowances granted for the depreciation of capital equipment (EU, 2004b), and as a result effective taxation increased. Related to EU accession, the new Member States had to cancel many of their tax incentives as they were in conflict with European Law. Some countries levy additional statutory taxes on enterprises. This is a common practice in the old member states, and among the new members in Hungary there is a local profit tax of $2 \%$, deductible from the base of the corporate tax. There are also real estate taxes levied in all EU-10 countries except Estonia ${ }^{6}$ and Slovenia, although they do not have a significant impact on the effective tax burden of companies since tax rates are relatively low and based on value in only three of the countries (Hungary, Latvia and Lithuania). Some companies are taxed under the PIT system: in Germany $85 \%$ of companies do not pay corporate taxes, and in Poland the figure is $93 \%$.

\section{Effective corporate tax rates in the $\mathrm{EU}-10$}

In order to have a clear image regarding the CIT levels, the effective taxes should be computed. The necessity for such a pursuit is that in addition to differences in statutory tax rates, countries may also have different tax bases that affect the level of taxes collected. Following OECD (2002), for the purpose of computing taxable profits, income may be subject to adjustment for exemptions (income excluded from the tax base), allowances (amounts deducted from gross income to arrive at taxable income), rate relief (a reduced rate of tax applied to a class of taxpayers or activities), tax credits (amounts deducted from tax liability), and tax deferral (a relief which takes the form of a delay in paying tax). Many countries reduced statutory tax rates, simultaneously broadening the tax base, mainly through less generous depreciation allowances. The EU-10 countries vary in the depreciation allowances that they grant against tax , but these differences are diminishing. Most old EU countries apply the straight line method (SL) for buildings and the option of SL or declining balance (DB) for machinery. The EU-10 pattern of capital allowances is converging to EU practices, although four countries still allow the more preferential DB method for buildings. Treatment of losses is also similar in the EU-10. With the exception of Estonia, none of the EU-10 countries allow for carry-back of losses, and carry-forward of losses is generally restricted to no more than 5 years. The Czech Republic has recently reduced the period during which tax losses can be carried forward from 7 to 5 years. Hungary has adopted the most liberal regime with no limit on the period during which losses can be carried forward. In general, these conditions are more restrictive than in the EU-15-while some allow a company to carry looses forward for a limited period (from 5 to 10 years), most countries allow for an unlimited period.

The trends confirm conclusions from other studies: in the second half of the 1990s, effective corporate tax rates were growing in the EU-15, but falling in the EU-10 countries. Since then, both 
trends appear to have reversed and some convergence taking place. In the old member states, this reflects falling statutory CIT rates in Germany, Finland, Sweden, and Portugal. It is to be noticed that at the beginning of the analyzed period, effective rates in the EU-15 were lower than in the EU-10, although nominal rates would suggest the opposite picture.

$\mathrm{It}^{7}$ is interesting to analyse the taxes which enterprises are supposed to pay depending on their geographical position on the continent. Several particularities occur for the Mediterranean, continental, Scandinavian or the new member states.

Table no.1

Effective corporate tax rates in the Mediterranean EU states

\begin{tabular}{|l|l|l|l|l|l|l|l|l|}
\hline & 1995 & 1996 & 1997 & 1998 & 1999 & 2000 & 2001 & 2002 \\
\hline ES & 8.6 & 9.9 & 13.1 & 12.2 & 14.5 & 15.4 & 14.0 & 16.2 \\
\hline FR & 9.6 & 11.1 & 12.6 & 12.3 & 14.5 & 14.8 & 16.6 & 14.2 \\
\hline IT & 12.2 & 13.6 & 15.5 & 9.4 & 10.6 & 9.0 & 11.2 & 9.9 \\
\hline PT & 10.4 & 12.3 & 13.9 & 14.1 & 16.8 & 19.4 & 17.0 & -- \\
\hline
\end{tabular}

Source: Intellinews

There is an obvious growth of the effective tax rates in the Mediterranean countries during 1995-2000. Italy could be seen as an exception, as rates here have fallen considerably starting with 1998. On the other hand Portugal outlines through higher effective rates compared to the other Mediterranean states.

Table no.2

Effective corporate tax rates in the continental EU states

\begin{tabular}{|l|l|l|l|l|l|l|l|l|}
\hline & 1995 & 1996 & 1997 & 1998 & 1999 & 2000 & 2001 & 2002 \\
\hline BE & 10.8 & 12.1 & 13.0 & 14.8 & 14.7 & 14.5 & 14.9 & 15.1 \\
\hline DE & 4.4 & 6.0 & 6.2 & 6.4 & 7.0 & 8.2 & 2.9 & 2.8 \\
\hline EL & 14.1 & 12.9 & 17.7 & 20.9 & 22.2 & 27.6 & 22.2 & 21.8 \\
\hline AT & 7.8 & 9.8 & 9.2 & 9.5 & 8.5 & 8.8 & 13.2 & 12.4 \\
\hline UK & 11.4 & 12.7 & 15.9 & 16.1 & 15.4 & 15.8 & 16.0 & 12.5 \\
\hline
\end{tabular}

Source: Intellinews

The states of the continental Europe seem similar to the ones from the Mediterranean Europe regarding the trend of the effective corporate tax rates. However, Germany can be seen as the single state which has by far a different fiscal system. Effective tax rates are almost missing for corporate. The policy in this area focuses on economical growth, new investments and enlargement of G.D.P.. Consequently there is the possibility of diminishing corporate tax rates. That has already happened in the recent years and seems to be the nowadays trend.

\footnotetext{
${ }^{7}$ European Commission Directorate General- Taxation and Customs Union, Eurostat, Structures of the taxation systems in The European Union, 2004
} 
Table no.3

Effective corporate tax rates in the Scandinavian EU states

\begin{tabular}{|l|l|l|l|l|l|l|l|l|}
\hline & 1995 & 1996 & 1997 & 1998 & 1999 & 2000 & 2001 & 2002 \\
\hline FI & 8.7 & 10.8 & 13.2 & 15.4 & 16.5 & 20.9 & 15.5 & 16.0 \\
\hline SE & 11.2 & 12.3 & 14.1 & 14.2 & 16.4 & 20.9 & 18.7 & 16.0 \\
\hline DK & 9.4 & 10.8 & 12.1 & 13.8 & 14.5 & 10.5 & 14.1 & 13.3 \\
\hline
\end{tabular}

Source: Intellinews

Denmark outlines by far in comparison to the other Scandinavian states (e. g. Sweden, Finland). Taxes collected in 2000 from corporate were extremely low and they seem to remain further much lower than in the other neighbour states.

Table no.4

Effective corporate tax rates in the new member states

\begin{tabular}{|l|l|l|l|l|l|l|l|l|}
\hline & 1995 & 1996 & 1997 & 1998 & 1999 & 2000 & 2001 & 2002 \\
\hline EE & -- & -- & 7.9 & 9.0 & 8.0 & 3.2 & 2.4 & -- \\
\hline LV & 8.6 & 10.2 & 7.9 & 7.9 & 6.3 & 5.4 & 5.7 & 5.7 \\
\hline LT & 5.7 & 4.9 & 6.6 & 5.5 & 3.5 & 2.4 & -- & -- \\
\hline HU & -- & -- & 7.7 & 8.7 & 9.4 & 10.5 & -- & -- \\
\hline PL & 20.6 & 22.0 & 21.5 & 19.1 & 16.4 & 15.8 & 14.9 & 13.5 \\
\hline SK & 21.3 & 16.0 & 14.2 & 13.9 & 12.6 & 11.6 & 10.9 & -- \\
\hline
\end{tabular}

Source: Intellinews

The average of the effective corporate tax rates in the new member states is definitely lower than the average rate in the old member states. Baltic States are the ones were tax burden is the most attractive for business development (one third of the average of the old member states). Poland is the new member state with a different fiscal approach than the other new member states. The taxes collected from enterprises are at the same level with the ones collected by the old members.

Table no.5

Effective corporate tax rates averages in the EU countries

\begin{tabular}{|l|l|l|l|l|l|l|l|l|}
\hline & 1995 & 1996 & 1997 & 1998 & 1999 & 2000 & 2001 & 2002 \\
\hline EU-15 & 10.1 & 11.6 & 13.4 & 13.6 & 14.6 & 15.6 & 14.9 & 13.8 \\
\hline EU-10 & 14.6 & 13.5 & 11.6 & 11.1 & 9.9 & 8.8 & 9.6 & 9.6 \\
\hline
\end{tabular}

Source: Intellinews

By analyzing the effective taxes collected in the two states categories, it turns out that the harmonisation of the European fiscal policies is a long and difficult process. The convergence can be obtained only through little steps towards this direction and debates on this topic seem never to come to an end. Both old and new member states are worried regarding effective tax rates and fair competitively.

\section{Competitively influenced by the adopted political policy}

One of the biggest concerns among old and new member states is that the use of transfer pricing in the presence of different tax burdens could lead to trade and tax distortion. While such concerns may seem valid for the old member countries given the generally lower corporate taxes in 
the new member countries, some of the latter have also been concerned about potential shifting of profits to lower tax countries within the region.

Most studies have focused on the determinants of FDI flows, but conceptually one should distinguish these from "real" investments in another country which may differ both because FDI flows may be directed to mergers and acquisitions (which do not contribute directly to increasing the capital stock in a country) and because real investments may be financed from capital raised in the host country. The determinants of these decisions, including tax considerations, are likely to be quite different. Other than the effective tax rate prevailing in a host country, the manner in which multinationals are taxed globally should play a role. This relates not only to potential double taxation in some countries, but even when this is not an issue, it matters whether the country of origin has a tax credit or exemption system: in the former case (the U.K, Ireland, Spain, and Greece) the tax rate in the host country in principle does not affect overall taxes, while in the latter case (other EU countries) it clearly makes a difference as there is no relation between taxes paid abroad and at home.

In caeteri paribus conditions, tax rates decrease corporate profits and so foreign direct investments are considerably influenced by the adopted fiscal policy. It is known that not only the fiscal policy, but also the dimension of the market or the human resources are influencing the foreign investments. Studies show that the most important issues for the investors are represented by the market state and the political stability, while the fiscal determinants are less important. It is also known, that fiscal systems are especially examined by international enterprises which develop their activities worldwide in different fields (assurances, banking etc.)

The behaviour of the companies is due to the dimension of the enterprises. Small companies are more sensitive regarding the political policy as they don't have the capacity to avoid taxation by promoting special strategies. Bigger companies have the chance to negotiate better fiscal conditions.

The expansion of the EU in May 2004 has stirred a controversial debate about "tax competition" among the EU members. Some countries (notably France and Germany) argue that the lower corporate tax rates in the new member countries present an unfair competitive advantage, and in one case having gone so far as to suggest that EU regional aid should be withdrawn from countries engaging in this practice as these countries do not need aid if they can afford to lower taxes. Other countries, including the new members but also some of the smaller old members (including Ireland), argue that low corporate income tax rates are a justifiable means to attract the investment needed for rapid growth and convergence.

\section{CONCLUDING REMARKS}

Corporate income tax rates have generally been reduced over the last decade, both in old and in new member countries. With more aggressive moves in recent years among the new member countries, statutory CIT rates are now significantly lower in the EU-10 than in the EU15, fuelling concerns among some old member states about unfair tax competition and renewed calls for harmonization of corporate taxes. However, these concerns should be put in proper perspective by comparing the overall cost of doing business in different countries: ${ }^{8}$

- Firstly, one should look at effective corporate income tax rates, which take into account differences in tax bases (arising from i.a. differences in depreciation allowances, treatment of losses, and inventory valuation methods);

- Secondly, one should assess the overall tax burden facing firms in different countries, including in particular taxes on labour (which are relatively high in the new EU member states) but also indirect taxes on goods;

\footnotetext{
${ }^{8}$ Markiewicz M., Corporate Income Taxation and FDI in the EU-10, 2004
} 
- Thirdly, production and distribution costs should be evaluated, in particular wages and productivity but also infrastructure and market access;

- Fourthly, and perhaps most important, investment decisions-whether by domestic or foreign investors-are likely to depend more on the overall investment climate, including political/social/macroeconomic stability, the rule of law, business regulations, financial market development, etc.

The results of this analyze suggest that while effective corporate tax rates were rising in the EU-15 during the second half of the 1990s in tandem with lowering of statutory rates (as tax bases were widened), lower statutory rates in the EU-10 were accompanied by lower effective rates resulting in the emergence of a significant gap in favor of the EU-10. However, in recent years there has been a significant degree of harmonization of tax bases - in part related to EU accession - and systems in the EU-10 are on the whole no longer more favorable than in the EU-15 as many incentive schemes have been abandoned. The new member countries gained a further advantage with the elimination of double taxation upon EU accession, although at a cost to their budgets. However, while countries may be tempted to lure capital through further reductions in statutory corporate tax rates, they would be well advised to consider such a strategy in the context of broader tax policy-in particular the countries that already have low CIT rates. Notably, reducing high labor taxes might well be more conducive to investment, employment generation, and poverty reduction.

It could be stated that convergence regarding fiscal systems has been partially accomplished, but there are still steps to make until companies and E.U. countries reach their final goals.

\section{REFERENCES}

1. Bernardi L., Profeta P., Tax Systems and Tax Reforms in Europe, Routledge, London 2004

2. Ohlsson L., Eurostat, Tax revenue in The E.U., Statistics in focus, Economy and Finance 2/2006

3. Markiewicz M., Corporate Income Taxation and FDI in the EU-10, 2004

4 . *** European Commission Directorate General- Taxation and Customs Union, Eurostat, Structures of the taxation systems in The European Union, 2004 